\title{
A Comparison of Equality in Kazakh and Turkic Languages of Siberia \\ Bibigul Yergaliyevna Yeskeldiyeva
}

bibigul05@mail.ru

\author{
Saule Zhaksylykbaevna Tazhibayeva \\ L. N. Gumilyov Eurasian National University, Mirzoyan str., 2, 010008, Astana, Kazakhstan \\ sauletazhibayeva@mail.ru
}

\section{Doi:10.5901/mjss.2015.v6n4s2p398}

\section{Abstract}

\begin{abstract}
The paper is devoted to a category of comparison in Kazakh and Turkic languages of Siberia. Kazakh is one of the Turkic languages of the Kipchak subgroup according to Baskakov's classification, or the Northwestem branch, Kipchak Turkic according to Lars Johanson's classification. Comparison is a mental act by which two objects are assigned a position on a predicative scale. In a semantic aspect all the languages express the same meaning of comparison: a comparison of equality or a comparison of inequality, but the forms expressing comparison in the world languages are quite different. Researchers have expressed a common opinion that comparison is a complex structural system of multi-level means of expression: lexical, morphological, syntatic. In the Turkic languages, the most productive way of expressing comparative relations of equality is the affix - $d A y$ that can be represented in the forms $N$ - $d A y$ and $V$-GAn-dAy. In the Kazakh language comparative marker -dAy can follow i) Nouns N-dAy and ii) Actional Nominal Verb form V-GAn- dAy. In our paper we will show the peculiarities of comparisons of equality in Kazakh, Altay Turkic, Khakass and Sakha Turkic.
\end{abstract}

Keywords: a comparison, a subject of comparison, a comparee, a standard of comparison, a module of comparison, a parameter.

\section{Introduction}

A comparison is known as a multidimensional and multi-level phenomenon. Comparison is an object of study of various disciplines.

Category of comparison is studied in philosophy as a scientific and philosophical method aimed at a single way of knowing the particular and universal; and plays a role in cognition and movement of item changes, but also in discovering causes of certain events: it is a way of classifying and ordering objects and phenomena, a necessary component of any inferences that one employs as evidence (Maslennikov, 1968).

In linguistics, a comparison is a fact of language. In most cases it is considered as syntactic or stylistic category. Comparison also reflects the results of cognitive human activities (Samoylenko, 2010).

Comparison is a consideration or estimate of the similarities or dissimilarities between two things or people (Dixon, 2005).

Comparison is a rhetorical strategy and method of organization in which a writer examines similarities and/or differences between two people, places, ideas, or things (Nordquist, 2014). Comparison is a mental act by which two objects are assigned a position on a predicative scale (Leon Stassen, 1984).

Comparison as the language category has been studied as the material of Indo-European languages by Russel Ultan (1972), M. Cheremisina (1976), Paul Andersen (1983), Leon Stassen (1984), Martin Haspelmath and Oda Buchholz (1998), Huddleston, R. and G. Pullum (2002), Pierluigi Cuzzolin and Christian Lehmann (2004), Dixon (2005), Eleni Bužarovska (2005), Alan C. Bale (2006), Sigrid Beck et al. (2009), Jessica Rett (2013), and others.

In Turkology, comparative constructions are been examined in Kazakh by T. Konyrov (1985) in Yakut (Sakha Turkic) language by Yu. Vassiliev (1986), in Altai language by L.N. Tybykova (1989), in Khakass by E.V. Kyrzhinakova (2010).

Researchers on the data of the languages of different typological families have expressed a common opinion that comparison is a complex structural system of multi-level means of expression: lexical, morphological (in most cases these include the degrees of comparison of adjectives and adverbs), syntax (comparative prepositions and conjunctions, case endings, comparative speed, etc., with which comparison becomes part of a simple / complicated comparative 
turnover offered by a complex sentence).

\section{Materials and Methods}

The objective of this study is to describe the grammatical ways of expressing the comparative relations by means of the affixes -day/ dey in Kazakh. These comparative affixes are the most productive and contribute to the formation of both simple and complex syntactic units (with the help of these affixes both simple and complex syntactic units are formed). The number of examples with this affix is over 1,500. The examples have been taken from Kazakh fiction and nonfiction.

We have applied various linguistic and general scientific methods and techniques: comparative method identified various meanings of lexis in all Turkic languages, with descriptive as well as method of component analysis making it possible to collect the data.

During the research a variety of methods and techniques of analysis has been used. The primary method of research is descriptive. When processing the empirical data we used methods of component and transformational analysis, comparative-typological method, and the method of structural modeling.

In the analysis of the data, we used the concepts that used in comparative semantics: the object of comparison, the standard of comparison and comparison module.

\section{Problem Statement}

It is well known that comparison (Latin 'comparatio') as a category of formal logic, suggests the presence of three elements: a) a concept that requires explanation (comparandum); b) a concept, that serves to illustrate (comparatum); c) a concept that serves as a "bridge" between two concepts (tertium comparationis) (Potebnya,1976).

Comparisons can be represented in simple and extended forms. In the simple comparison only two objects or phenomenon are compared under one common ground. In the extended comparison two or more objects are compared for many common features. The analysis of our data shows that the most frequent type of comparison in Kazakh are simple comparisons, they constitute about $80 \%$. The model of simple comparison can be represented in Kazakh and other Turkic Languages (Altay Turkic, Sakha Turkic, Khakass etc.) by the model N-dAy. Whereas, the model of a complex comparison is represented by the form V-GAn-dAy.

In our study we will pay special attention to the peculiarity of the N-dAy form in Kazakh and Turkic languages of Siberia (Altay Turkic, Sakha Turkic, Khakass).

Kazakh is one of the Turkic languages of Kipchak subgroup (Baskakov, 2006) or Northwestem branch, Kipchak Turkic according to Lars Johanson's classification (Johanson, 1998).

The Altay Turkic language belongs to Kirgiz-Kipchak group. The Khakass language belongs to the Kahass subgroup in the Uighur group. The Yakut language is one of the Turkic languages of the Yakut subgroup in the Uighur group (Baskakov, 2006).

\section{The Ways of Expressing Comparative Relations by Means of the Model N-dAy in the Kazakh Language}

In Turkic languages, the most productive way of expressing comparative relations is the affix - $d A y$ that can be represented in the form $\mathrm{N}-d A y$.

Comparison constitutes a proposition of comparison that can be encoded in various types of comparative syntactic constructions (CC). Following Maya Cheremisina (1976), we understand CC as constructions involving a module of comparison, i.e. a predicative scale, which is usually encoded as a gradable predicate, and two objects:

1) the object of comparison (the comparee NP), and

2) the standard of comparison, i.e. the object that serves as the "yard-stick" for comparison

Comparison is expressed by various syntactic constructions consisting of several components expressing a comparee, a standard, and a parameter.

Each component, which is mentioned above, means the following:

e.g She is sly as a fox

- 1) Comparee, i.e. the entity which is compared - 'she';

- 2) Standard, i.e. the entity serving for comparison - 'fox';

- 3) Standard Marker, i.e.the indicator of a standard -'as';

- 4) Parameter, the common ground on which items are compared - 'sly' 
In our research we use the following abbreviations:

CMP-Comparee

STAN-Standard

STM-Standard marker

PARA-Parameter

PAM-Parameter marker

e.g.

'Ayzhan is as beautiful as Zhanar.'

$\begin{array}{ccc}\text { Ayžan } & \text { Žanar-day } & \text { sulw } \\ \text { NP } & \text { NP-CMPR } & \text { beautiful } \\ \text { CMP } & \text { STAN-STM } & \text { PARA }\end{array}$

\subsection{Canonical and non-canonical CC}

Comparison is expressed by Canonical and non-canonical CC.

\subsubsection{Canonical comparative constructions}

The comparative relations are usually expressed in canonical comparative constructions i.e. in a standardized way, by grammatical means.

'His car is as expensive as (his) house.'

$\begin{array}{cccc}\text { Onïn } & \text { mašina-si } & \text { üy-dey } & \text { qümbat } \\ \text { His } & \text { car-POSS3 } & \text { house-CMPR } & \text { expensive } \\ & \text { CMP } & \text { STAN-STM } & \text { PARA }\end{array}$

'Houses look like an egg'

$\begin{array}{cccc}\text { Üy-ler } & \text { žumiirtqa-day } & \text { bolip } & \text { körinedi } \\ \text { house-PL } & \text { egg-CMPR } & \text { be-AUX-CVB } & \text { overspread-PST3 } \\ \text { CMP } & \text { STAN-STM } & & \text { PARA }\end{array}$

'He danced like Samat danced'

$\begin{array}{cccc}\text { Ol } & \text { Samal } & \text { bile-gen-dey } & \text { bile-di } \\ \text { He } & \text { Samal } & \text { dance-PP-CMPR } & \text { dance-PST3 } \\ \text { CMP } & & \text { STAN-STM } & \text { PARA }\end{array}$

The STM-Standard marker is expressed in a canonical way: by a special comparative morphological marker, or a comparative postposition. Here it is expressed morphologically by the affix - $d A y$

The CMP is normally the subject of a canonical CC.

The PARA is its predicate.

\subsubsection{Non-canonical CC}

In non-canonical constructions, the comparative relations in Kazakh are expressed lexically with words as 'ten' - equal, by means of verbs as 'uqsa=w'- with a lexical semantics in English as 'be alike', 'resemble', 'look like'.

e.g.

'The price of the car is equal to the price of the house' $\approx$

'The car is as expensive as the house.'

$\begin{array}{ccccc}\text { Mašina-nin } & \text { baya-sï } & \text { üy-din } & \text { bayas Ï- na } & \text { ten } \\ \text { car-GEN } & \text { price-POSS3 } & \text { house-GEN } & \text { price-POSS3-ABL } & \text { equal }\end{array}$


CMP

PARA

STAN

PARA

STM

'His eyes resemble your eyes.'

$\begin{array}{ccccc}\text { Onin } & \text { köz-i } & \text { senin } & \text { köz-in-e } & \text { uqsa-idï } \\ \text { car-GEN } & \text { eye-POSS3 } & \text { your } & \text { eye-POSS2SG-DAT } & \text { resemble-PRS3 } \\ \text { CMP } & \text { PARA } & \text { STAN } & \text { PARA } & \text { STM }\end{array}$

'He resembles (looks like) his father.'

$\begin{array}{ccc}\text { Ol } & \text { äkesi-ne } & \text { uqsai-dï } \\ \text { he } & \text { father-DAT } & \text { resemble-PRS3 } \\ \text { CMP } & \text { STAN } & \text { STM }\end{array}$

\subsection{Proposition of comparison in simple and complex sentences}

Comparison constitutes a proposition of comparison that can be encoded in various types of comparative syntactic constructions (CC). Proposition of comparison can be expressed by simple sentences built according to various patterns:

'Her eyes shone like stars.'

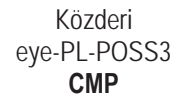

CMP

'She's beautiful like the moon.'

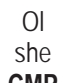

CMP
Ol žuldiz-day

star-CMPR

STAN-STM žarqïra-dï

shine-PST3

PARA ay-day

moon-CMPR

STAN-STM sulw beautiful

PARA

'The hard months stretched like the year.'

$\begin{array}{cccc}\text { Awir } & \text { ay-lar } & \text { žil-day } & \text { sozill-dï } \\ \text { hard } & \text { month-PL } & \text { year-CMPR } & \text { stretch-PST3 } \\ & \text { CMP } & \text { STAN-STM } & \text { PARA }\end{array}$

'He roared like a lion'

$\begin{array}{ccc}\text { Ol } & \text { arïstan-ša } & \text { aqïr-dï } \\ \text { he } & \text { lion-CMPR } & \text { roar-PST3 } \\ \text { CMP } & \text { STAN-STM } & \text { PARA }\end{array}$

A proposition of comparison can be expressed in complex sentences where the patterns of simple comparative clauses undergo reductions and transformations:

'We heard that he was roaring like a lion.' $\approx$ 'We heard he roared like a lion.'

$\begin{array}{ccccc}\text { Biz } & \text { ONIN } & \text { ARYSTAN-ŠA } & \text { AQYRYANÏN } & \text { estidik } \\ \text { We } & \text { he-GEN } & \text { lion-CMPR } & \text { rOar-ACC } & \text { hear-PST1 } \\ & \text { CMP } & \text { STAN-STM } & \text { PARA } & \end{array}$

'The mirage rose glowing in the sun white villages and some houses look like an egg.'

$\begin{array}{cccc} & \text { Žarïq künde šangiyïp köringen aq awldardï sayïm köterip keybir } & \\ \text { ÜYLER } & \text { ŽUMIIRTQA-DAY } & \text { BOLÏP } & \text { KÖRINEDI } \\ \text { house-PL } & \text { egg-CMPR } & \text { be-CVB } & \text { look-PRS3 } \\ \text { CMP } & \text { STAN-STM } & & \text { PARA }\end{array}$


'Having met in a dark cemetery we clashed like two angry bears.'

Qaranyï beyittin išinde ekewmiz šappa-šap kelip qapsiira qušaqtasïp, talasqan eki

CMP

$\begin{array}{lccc}\text { AYUW-DAY } & \text { SIRESIP } & \text { QATÏP } & \text { QALDÏQ } \\ \text { bear-CMPR } & \text { stretch-CVB } & \text { curdle-CVB } & \text { stay-PST1 } \\ \text { STAN-STM } & \text { PARA } & \text { PARA } & \text { PARA }\end{array}$

\section{Semantic Types of Constructions of Comparison}

A logical operation of comparison results either in similarity (equality), or difference of two entities. There are only two basic results that can be expressed in a construction of comparison:

(a) identity or similarity,

(b) difference.

If the result shows that the two entities in question do not differ with respect to the quality or property, we are dealing with a comparison of equality:

John is as tall as Mary.

On the other hand, if two entities do indeed differ, then the result will be termed as a comparison of inequality:

- John is taller than Mary. (Andersen, 1983)

Relations of identity are expressed in the following types of constructions of comparison:

- equative

- similative

Martin Haspelmath and Oda Buchholz (1983) consider simulative constructions together with equative as they have close semantic and formal similarities with equatives. Equatives express equal extent, and similatives express an equal manner.

\subsection{Comparison of equality in Turkic Languages.}

The term equative is applied to comparative-like constructions in which the degrees compared are identical rather than distinct. The parameter here is expressed by a nominal.

Equative constructions in Kazakh:

'Ayzhan (is) as beautiful as Zhanar.' $\approx$

'Ayzhan is beautiful to the same extent as Zhanar.' (the equal extent of the quality "beautiful" is expressed)

The standard marker is expressed by the affix - day.

$\begin{array}{ccc}\text { Ayžan } & \text { Žanar-day } & \text { sulw } \\ \text { NP } & \text { NP-CMPR } & \text { beautiful } \\ \text { CMP } & \text { STAN-STM } & \text { PARA }\end{array}$

Altay Turkic (Tybykova 1989):

le Wgar ta neniyn de wčwn ol sÿt-tiyy ak kwlwn-dï sÿÿgen.

'le Ugar loved that foal white as milk.'

The standard marker is expressed by the affix - tiyy.

$\begin{array}{ccc} & \text { le Wgar ta neniyn de wčwn ol } \\ \text { sÿt-tiyy } & A k & k w / w n-d i \\ \text { milk-CMPR } & \text { white } & \text { foal-ACC } \\ \text { STAN-STM } & \text { PARA } & \text { CMP }\end{array}$

sÿÿgen

look-PRS3

Khakass (Kyrzhinakova 2010):

Xarayï xoy xaray-ïn-dag.

'Her eyes are as sheep's eyes.' 


\section{Xarayï \\ eye-POSS3 \\ CMP}

xoy

sheep

STAN

\author{
xaray-ïn-dag \\ eye-POSS3-CMPR \\ STAN-STM
}

Tiz-i xozan tiz-in-deg.

'Her teeth are as a hare's teeth.'

$\begin{array}{cc}\text { Tiz-i } & \text { xozan } \\ \text { tooth-POSS3 } & \text { hare } \\ \text { CMP } & \text { STAN }\end{array}$

tiz-in-deg

tooth-POSS3-CMPR

STAN-STM

Petya Kolya osxas tabïrax.

'Peter is as quick as Kolya.'

$\begin{array}{cccc}\text { Petya } & \text { Kolya } & \text { osxas } & \text { tabïrax } \\ \text { NP } & \text { NP } & \text { PSTP } & \text { beautiful } \\ \text { CMP } & \text { STAN } & \text { STM } & \text { PARA }\end{array}$

Sïrayï izig kös osxas hïzïl.

'Face is as red as hot coals.'

$\begin{array}{ccccc}\text { Sïrayï } & \text { izig } & \text { kös } & \text { osxas } & \text { hïzïl } \\ \text { Face-POSS3 } & \text { hot } & \text { coal } & \text { PSTP } & \text { red } \\ \text { CMP } & & \text { STAN } & \text { STM } & \text { PARA }\end{array}$

Tiyrek-če sïn-nïy.

'The height is like a poplar.'

$$
\begin{gathered}
\text { Tiyrek-če } \\
\text { poplar-CMPR } \\
\text { STAN-STM }
\end{gathered}
$$

sïn-nïy height-PROL

CMP

Tiykpe-če ayïl-ï čox.

'Stupid as a stand.'

$$
\begin{gathered}
\text { Tiykpe-če } \\
\text { stand-CMPR } \\
\text { STAN-STM }
\end{gathered}
$$

$$
\begin{gathered}
\text { ayïl-ï čox } \\
\text { mind-POSS3-NEG } \\
\text { CMP }
\end{gathered}
$$

Sakha Turkic (Vasileyv 1986):

Marba siyre'ye' bwspwt alaadï kwrdwk tögürük.

'Marbach's face (is) round like a fried pancake.'

$\begin{array}{cccccc}\text { Marba } & \text { siyre'ye' } & \text { bwspwt } & \text { alaadï } & \text { kwrdwk } & \text { tögürük } \\ \text { Marbach } & \text { face-POSS3 } & \text { fried } & \text { pancake } & \text { PSTP } & \text { round } \\ & \text { CMP } & & \text { STAN } & \text { STM } & \text { PARA }\end{array}$

Asfalt taas wwlwssa ostwol nwwrw kwrdwk kiyle'rke'y.

'A paved street is like the smooth surface of a table.'

$\begin{array}{cccccc}\text { Asfalt taas } & \text { wwlwssa } & \text { ostwol } & \text { nwwrw } & \text { kwrdwk } & \text { kiyle'rke'y } \\ \text { paved } & \text { street } & \text { table } & \text { surface } & \text { PSTP } & \text { smooth } \\ & \text { CMP } & \text { STAN } & \text { STAN } & \text { STM } & \text { PARA }\end{array}$


Tanïraqa olws sitiii, de'giye' kwrdwk ïnïrik.

'Her terrible claws are very sharp, like a hook.'

\begin{tabular}{|c|c|c|c|c|}
\hline $\begin{array}{l}\text { 「an̈̈raqa } \\
\text { CMP }\end{array}$ & $\begin{array}{l}\text { olws } \\
\text { STAN }\end{array}$ & sitiii, & de'giye' & $\begin{array}{l}\text { kwrdwk } \\
\text { STM }\end{array}$ \\
\hline
\end{tabular}

\subsection{Comparison of similarity in Turkic Languages.}

A Similative construction is a construction expressing sameness or similarity of manner or being.

The parameter here is expressed by a verb.

Similative constructions in Kazakh:

Ol arïstan-day soyïs-t-ï.

'He fought like a lion .' $\approx$ 'He fought in the same way as a lion.' (equal manner is expressed)

$\begin{array}{ccc}\text { Ol } & \text { arïstan-day } & \text { soyïs-tï } \\ \text { he } & \text { lion-CMPR } & \text { fight-PST3 } \\ \text { CMP } & \text { STAN-STM } & \text { PARA }\end{array}$

Altay Turkic (Tybykova 1989):

lïlamaštïn ïrregiy, kenerte ÿrkiydiyp iyügen kwčkaš čillap, sert e'diyp kalgan.

'Dylamash's heart shuddered like a suddenly frightened bird.'

$\begin{array}{cccc}\text { ï̈regiy } & \text { kwčkaš } & \text { čillap } & \text { sert } \\ \text { heart-POSS3 } & \text { bird } & \text { PSTP } & \text { shudder } \\ \text { CMP } & \text { STAN } & \text {-STM } & \text { PARA }\end{array}$

Khakass (Kyrzhinakova 2010):

Siyn miyni an-ïuax-tï čliy in-de twd-arya xïn-ča-zïn.

'You want to keep me in a hole as a little animal.'

$\begin{array}{ccc}\text { miyni } & \text { an-ïчax-tï } & \text { čiliy } \\ \text { I-ACC } & \text { beast-ACC } & \text { PSTP } \\ \text { CMP } & \text { STAN } & \text { STM }\end{array}$

Ariyna! Čoylan-ma! - wdwr atijya tÿs-ken, xoosxa kÿske-zer chiliy.

'Arina! Do not lie! - jumped to her like a cat on a mouse.'

$\begin{array}{ccc}\text { atija } & \text { xoosxa } & \text { ciliy } \\ \text { jump-CVB } & \text { cat } & \text { PSTP } \\ \text { PARA } & \text { STAN } & \text { STM }\end{array}$

Harti ča yaxaala-p, ol tÿrle-en.

'He was flying and flitting like a hawk.'

$\begin{array}{cccc}\text { Harti ča } & \text { yaxaala-p } & \text { ol } & \text { tÿrle-en } \\ \text { hawk-PROL } & \text { fly-CVB } & \text { he } & \text { flit-PST3 } \\ \text { STAN-STM } & \text { PARA } & \text { CMR } & \text { PARA }\end{array}$

\subsection{Standard markers in equative and simulative constructions.}

In Kazakh, Altay Turkic and Khakass equative and simulative constructions are formed by the same means, and are closely related to each other. In such languages (where they are expressed in a very similar way) we may distinguish equative constructions from simulative by analyzing their structural features and determining whether the construction expresses sameness of extent or sameness of manner. 
Compare:

Kazakh

'Ayzhan (is) as beautiful as Zhanar.'- equative construction

$\begin{array}{ccc}\text { Ayžan } & \text { Žanar-day } & \text { sulw } \\ \text { NP } & \text { NP-CMPR } & \text { beautiful } \\ \text { CMP } & \text { STAN-STM } & \text { PARA }\end{array}$

'He is shining like a star.' - similative construction

$\begin{array}{ccc}\text { Ol } & \text { žuldiz-day } & \text { žarkïra-y-dï. } \\ \text { he } & \text { star-CMPR } & \text { shine-PRS3 } \\ \text { CMP } & \text { STAN-STM } & \text { PARA }\end{array}$

The standard marker in both constructions in Kazakh is the affix - dayl-dey.

Altay Turkic (Tybykova 1989):

le Wgar ta neniyn de wčwn ol sÿt-tiyy ak kwlwn-dï sÿ̈̈gen.

'le Ugar loved that foal white as milk.' (equative)

Karakwy kiyriyp le kelerde, tïndanïp, kiyske-diyy lïmjan altaganïs, örko körgön iyyt-tiyy, čeber ön öl ög öniys.

'As soon as it got dark, treading softly, like a cat, carefully making his way as a dog when she saw a gopher, we listened.' (similative)

The standard marker in both constructions in Altay Turkic is the affix - tiyy/ diyy.

The marker of standard is one of the obligatory components as it expresses a comparison. The marker of standard in equative and similative constructions can be formed in synthetic and analytical ways.

\subsubsection{The standard marker in Kazak equative constructions.}

A synthetic marker of standard in Kazakh equative constructions is formed with the help of a comparative affix -day/-dey. As in:

'Ayzhan (is) as beautiful as Zhanar.'

$\begin{array}{ccc}\text { Ayžan } & \text { Žanar-day } & \text { sulw } \\ \text { NP } & \text { NP-CMPR } & \text { beautiful } \\ \text { CMP } & \text { STAN-STM } & \text { PARA }\end{array}$

'He (is) as strong as you.'

$\begin{array}{ccc}\text { Ol } & \text { sen-dey } & \text { küšti } \\ \text { he } & \text { you-CMPR } & \text { strong } \\ \text { CMP } & \text { STAN-STM } & \text { PARA }\end{array}$

An analytical marker of standard in Kazakh is formed with the help of a postpositions siyaqtï / sekildi. See:

'Ayzhan (is) as beautiful as Zhanar.'

$\begin{array}{ll}\text { Ayžan } & \text { Žanar } \\ \text { NP } & \text { NP } \\ \text { CMP } & \text { STAN }\end{array}$
siyaqti/sekildi
PSTP
STM

sulw

beautiful

NP

PARA

'He (is) as strong as you.'

$\begin{array}{cccc}\text { Ol } & \text { sen } & \text { siyaqti/sekildi } & \text { küšti } \\ \text { he } & \text { you } & \text { PSTP } & \text { strong } \\ \text { CMP } & \text { STAN } & \text { STM } & \text { PARA }\end{array}$


Both synthetic and analytical markers follow a standard of comparison.

\subsubsection{The standard marker in Kazak similative constructions.}

The marker of standard in Kazak similative constructions like equative constructions is formed in synthetic and analytical ways.

The affix -day/-dey is frequently used as a synthetic marker for standard in similative constructions. See:

'He shines like a star.'

$\begin{array}{ccc}\text { Ol } & \text { žuldiz-day } & \text { žarqïra-y-dï } \\ \text { he } & \text { star-CMPR } & \text { shine-PRS3 } \\ \text { CMP } & \text { STAN-STM } & \text { PARA }\end{array}$

'His hands became frozen like ice because of the frost.'

$\begin{array}{ccccc}\text { Qol-dar-ï } & \text { ayaz-dan } & \text { muz-day } & \text { qatïp } & \text { qalyan } \\ \text { hand-PL-POSS3 } & \text { frost-ABL } & \text { ice-CMPR } & \text { freeze-CVB } & \text { stay-PTCP } \\ \text { CMP } & & \text { STAN-STM } & \text { PARA } & \text { PARA }\end{array}$

One more affix serving as a synthetic marker of standard in similative constructions is the affix - ša/- še. Look at the examples:

'He roared like a lion'

$\begin{array}{ccc}\text { Ol } & \text { arïstan-ša } & \text { aqïrdï } \\ \text { he } & \text { lion-CMPR } & \text { roar-PST3 } \\ \text { CMP } & \text { STAN-STM } & \text { PARA }\end{array}$

'He began to understand many things as (like) an adult.'

$\begin{array}{cccccc}\text { Ol } & \text { köp } & \text { närse-ni } & \text { ulken-der-še } & \text { payïmda-y } & \text { basta-dï. } \\ \text { he } & \text { many } & \text { thing-ACC } & \text { adult-PL-CMPR } & \text { understand-CVB } & \text { begin-PST3 } \\ \text { CMP } & & & \text { STAN-STM } & \text { PARA } & \end{array}$

Similative constructions are formed in an analytical way with the help of postpositions siyaqti / sekildi:

'He went jumping like a little boy.'

$\begin{array}{cccccc}\text { Ol } & \text { kiškentay } & \text { bala } & \text { siyaqti/sekildi } & \text { sekir-ip } & \text { ket-t-i. } \\ \text { he } & \text { little } & \text { boy } & \text { PSTP } & \text { jump-CVB } & \text { go-PST3 } \\ \text { CMP } & & \text { STAN } & \text { STM } & \text { PARA } & \end{array}$

\subsubsection{The standard markers in Altay Turkic, Khakass, and Sakha Turkic equative and similative constructions.}

The equative constructions in Altay Turkic can be expressed by the affix - tiyy/ diyy (synthetically). In Khakass such constructions can also be formed synthetically with the help of the affixes -dag/-deg; -ča/ -če or analytically by the postposition 'osxas' - 'as, like'. In Sakha Turkic comparison of equality is represented by the 'kwrdwk' - 'as,like'.

The similative constructions in Altay Turkic can be expressed synthetically by affix - tiyy/ diyy or analytically by the postposition 'čilap' - 'as,like'. In Khakass similative constructions can be formed also synthetically with the help of the affix -ča/-če or analytically by the postposition 'chiliy' - 'as,like'.

The result of our analysis is outlined in the table below:

\begin{tabular}{|l|c|c|c|c|}
\hline Language & \multicolumn{2}{|c|}{ Equative Constructions } & \multicolumn{2}{c|}{ Similative Constructions } \\
\hline & Synthetic STM & Analytical STM & Synthetic STM & Analytical STM \\
\hline Kazakh & -day/-dey & siyaqtï/sekildi & -day/-dey; -ša/-še & siyaqtil/sekildi \\
\hline Altay Turkic & tiyy/diyy & & tiyy/diyy & čilap \\
\hline Khakass & -dag/-deg; -čal-če & osxas & -čal-če & chiliy \\
\hline Sakha Turkic & & kwrdwk & & \\
\hline
\end{tabular}




\section{Conclusion}

In this study we have examined the comparison of equality in Kazakh and the Turkic languages of Siberia. The comparison of equality is expressed in equative and similative constructions. Equatives and similatives in Kazakh language are expressed in the same way, i.e. they have the same standard markers. The standard marker can be synthetic or analytic. The synthetic standard markers in Kazakh comparisons of equality are expressed with the help of affixes day/dey,tay/tey, ša/še. The affix of comparison -day/dey is used in both constructions, whereas the affix - šal še is used only in simulative ones. The affix -day/dey can be attached to any noun, the affix - ša/ še only to animate nouns. The analytic standard marker in Kazakh comparisons of equality is expressed with the help of postpositions 'siyaqti', 'sekildi'. The postpositions 'siyaqti', 'sekildi' form the standard NP in both constructions.

Kazakh and Turkic languages of Siberia have common features when expressing the comparison of equality. In Kazakh, Altay Turkic and Khahass variations of the same affixes are used. The standard marker in these languages can be formed in synthetic and analytic ways.

Equative and similative constructions are very similar and closely related. Only the parameter helps us to distinguish them, as the parameters in these constructions are different. The parameter in the equative construction is expressed by an adjective. In equative constructions, the adjective does not bear any special marker of equality of the compared entities. However, the parameter may have an adverb expressing the grade of quality which is shared by both the comparee and the standard. The parameter in the simulative constructions may be expressed by any finite or nonfinite verb form. Equatives express equal extent of a parameter, and similatives express equal manner of a parameter. Therefore the presence of a parameter is obligatory as it differentiates equatives from similatives.

The analysis shows that all constructions of equality possess common features. They constitute the same components such as a comparee, a standard, a standard marker and a parameter.

Abbreviations

1- first person

2- second person

3- third person

$\mathrm{ABL}$ - ablative

ACC - accusative

AUX - auxiliary

CMPR - comparison

CVB - converb

DAT - dative

GEN - genitive

NEG - negative

$\mathrm{NOM}$ - nominative

$\mathrm{NP}$ - nominal phrase

$\mathrm{PL}$ - plural

POSS - possessive

PRS - present

PP - past participle

PST - past

SG - singular

\section{References}

Andersen, Paul K. (1983). Word order typology and comparative constructions. Amsterdam [etc.]: Benjamins

Bale, A. (2006). Comparatives and the distributive/cumulative distinction. Canadian Linguistic Association (CLA) Conference 2006. Toronto, 27 - 30 May 2006.

Baskakov N.A. (2006). Tjurkskie jazyki. (2nd ed.). Moscow, KomKniga.

Bužarovska E. (2005). Equality versus similarity constructions in English. Journal of Language and Linguistics 4 (1), 74-99

Cheremisina M. (1976). Sravnitel'nye konstrukcii russkogo jazyka. Novosibirsk: Nauka

Cuzzolin P. \& Lehmann Ch. (2004). Comparison and Gradation. In: Booij, Gerd/Mugdan, Joachim/Skopeteas, Stavros (Hrsg.), Morphologie. Halbband 2. Ein internationales Handbuch zur Flexion und Wortbildung. Berlin/New York, de Gruyter: 1212-1220.

Dixon, Robert M.W. (2005). Comparative constructions in English. Studia Anglica Posnaniensia: international review of English Studies, Vol. 41 
Haspelmath, Martin \& Buchholz, Oda. (1998). Equative and similative constructions in the languages of Europe. In: van der Auwera, Johan (ed.). Adverbial constructions in the languages of Europe, pp. 277-334. Berlin: Mouton de Gruyter.

Huddleston, R. and Pullum G. (2002). The Cambridge gammar of the English Language. Cambridge University Press.

Johanson, Lars. (1998). The History of Turkic. In Lars Johanson \& Éva Ágnes Csató (eds). The Turkic Languages. London, New York: Routledge

Konyrov T. (1985). Strwktwrno-semanticheskaya priroda sravneniya v kazahskom yazi'ke. Alma-Ata: Mektep.

Kyrzhinakova Je.V. (2010). Sposoby vyrazhenija sravnenija v hakasskom jazyke. (Dissertation). Abakan. http://www.dissercat. com/content/sposoby-vyrazheniya-sravneniya-v-Khakasskom-yazyke

Maslennikov M. (1968). Metodologicheskoe znachenie sravneniya v nauchnom poznanii. Voronezh.

Nordquist R. (2014). Glossary of Grammatical and Rhetorical Terms. From http://grammar.about.com

Potebnya A. (1976). Estetika i poetika. Moscow, M.: Iskusstvo.

Rett Jessica. (2012). Similatives and the argument structure of verbs. Natural Language and Linguistic Theory, Vol. 31, 1101-1137

Samoylenko E. (2010). Problemyi sravneniya v psihologicheskom issledovanii [Tekst]: monografiya -E.S. Samoylenko; Institut psihologii RAN (M.). - M. Institut psihologii RAN.

Sigrid Beck, et al. (2009). Crosslinguistic variation in comparison constructions. Linguistic Variation Yearbook 9, 1-66

Stassen, Leon. (1984). The Comparative Compared. In: Journal of Semantics, Vol. 3, 143-182.

Tybykova L. (1989). Sravnitel'nye konstrukcii altajskogo jazyka. (Synopsis) Alma-Ata.

Ultan, Russell. 1972. Some Features of Basic Comparative Constructions. Working Papers on Language Universals (Stanford) 9. 117162

Vassiliev Yu. (1986). Sposoby vyrazhenija sravnenija v jakutskom jazyke. Novosibirsk. 